\title{
Pernikahan Usia Dini dan Perspektifnya Menurut Hukum Islam di Desa Persiapan Berinding Kecamatan Kopang Kabupaten Lombok Tengah
}

\author{
Sri Hariati \\ Fakultas Hukum, Universitas Mataram, Nusa Tenggara Barat, Indonesia
}

\author{
Article history \\ Received: 02-11-2021 \\ Revised: 15-11-2021 \\ Accepted: 22-11-2021 \\ *Corresponding Author: \\ Sri Hariati, \\ Fakultas Hukum, \\ Universitas Mataram, \\ Mataram, Indonesia; \\ Email: \\ srihukum80@gmail.com
}

\begin{abstract}
The practice of early marriage is currently a common thing among the community, especially in rural areas where there is less information about the impact of this behavior. The purpose of this counseling is to provide education about the causes of early marriage and the impact it has, as well as its implications according to Islamic law. The method used in this counseling activity is using the lecture and discussion method. Based on the results of the evaluation carried out by the extension worker after the extension activity was completed, in general it could be said that the participants had only just learned the material presented. Lack of public awareness of deviant behavior carried out by men and women (early marriage), especially among adolescents who are not medically old enough, has resulted in this practice still occurring. So that it has become a joint task for parents in educating their children as well as possible both in the fields of religion and education so that our children avoid these actions.
\end{abstract}

Keywords: marriage; early; age; youth

Abtrak: Peraktik pernikahan dini saat ini merupakan hal yang sering terjadi di kalangan masyarakat, khususnya di daerah pedesaan yang kurang mendapat informasi mengenai dampak perilaku tersebut. Tujuan penyuluhan ini untuk memberikan edukasi mengenai penyebab terjadinya pernikahan di usia dini serta dampak yang ditimbulkannya, serta implikasinya menurut hukum islam. Metode yang dilakukan pada kegiatan penyuluhan ini adalah mengunakan metode ceramah dan diskusi. Berdasarkan hasil evaluasi yang dilakukan oleh penyuluh setelah selesai kegiatan penyuluhan ini secara umum dapat dikatakan bahwa para peserta baru mengetahui materi yang disampaikan. Kurangnya kesadaran masyarakat terhadap perilaku menyimpang yang dilakukan oleh laki-laki dan perempuan (pernikahan dini) terutama di kalangan remaja yang secara medis belum cukup umur, mengakibatkan praktik tersebut masih terjadi. Sehingga sudah menjadi tugas bersama bagi para orang tua dalam mendidik anaknya dengan sebaik-baiknya baik dalam bidang agama dan pendidikan agar anak-anak kita terhindar dari perbuatan tersebut.

Kata Kunci: : pernikahan; usia; dini; remaja

\section{PENDAHULUAN}

Angka pernikahan dini di banyak Negara terus meningkat dari tahun ke tahun dan selalu berhubungan dengan berbagai upaya perlindungan hokum terhadap anak. Pada tahun 2015, ada sekitar 142 juta anak perempuan yang melakukan pernikahan sebelum waktunya (Candraningrum D., 2016:35). Di Indonesia, pernikahan dini sudah menjadi fenomena nasional, budaya menjadi faktor yang berpengaruh besar terhadap pola kehidupan dalam masyarakat, termasuk dalam pernikahan dini. 
Pernikahan berbagai etnis, memperlihatkan bahwa masalah perkawinan dini perlu sangat diperhatikan. Indonesia menempati peringkat ke-37 dengan jumlah pernikahan di bawah umur tertinggi di dunia, dan ke 2 di Asia Tenggara. Tentu bukan hal yang membanggakan karena ini mempengaruhi kepadatan penduduk, karena berpotensi terhadap kelahiran yang tinggi pula.

Permasalahan pernikahan dini menjadi sangat penting untuk diperhatikan, bahkan ada suatu desa di Indonesia yang sangat merespon positif terhadap pernikahan dini ini. Karena mereka beranggapan bahwa pernikahan dini adalah suatu tradisi dari nenek moyang yang harus dilestarikan secara turun menurun. Kebanyakan yang melakukan pernikahan di usia dini adalah anak yang berusia di bawah 16 tahun, bisa di rata-rata mereka adalah yang berusia 13-15 tahun (Muntamah et al, 2019).

Kehamilan di usia remaja berpotensi meningkatkan risiko kesehatan pada wanita dan bayi. Ini karena sebenarnya tubuh belum siap untuk hamil dan melahirkan. Wanita yang masih muda masih mengalami pertumbuhan dan perkembangan. Jika ia hamil, maka pertumbuhan dan perkembangan tubuhnya akan terganggu. Biasanya kondisi yang muncul akibat hamil di usia muda yaitu:

$\checkmark$ Tekanan Darah Tinggi. Hamil di usia remaja berisiko tinggi terhadap tingginya tekanan darah. Seseorang mungkin dapat mengalami preeklampsia yang ditandai dengan tekanan darah tinggi, adanya protein dalam urine, dan tanda kerusakan organ lainnya.

$\checkmark$ Anemia. Anemia disebabkan karena kurangnya zat besi yang dikonsumsi oleh ibu hamil. Anemia saat hamil dapat meningkatkan risiko bayi lahir prematur dan kesulitan saat melahirkan.

$\checkmark$ Bayi Lahir Prematur dan BBLR. Bayi prematur biasanya memiliki berat badan lahir rendah (BBLR) karena sebenarnya ia belum siap untuk dilahirkan. Bayi lahir prematur berisiko mengalami gangguan pernapasan, pencernaan, penglihatan, kognitif, dan masalah lainnya.

$\checkmark$ Ibu Meninggal Saat Melahirkan. Perempuan di bawah usia 18 tahun yang hamil dan melahirkan berisiko mengalami kematian saat persalinan. Ini karena tubuhnya belum matang dan siap secara fisik saat melahirkan (Halodoc.com: 2020)

Dampak lainnya yakni pada kesehatan mental, dampak tersebut sangat dirasakan oleh anak perempuan, hal tersebut sangat fatal disebabkan anak perempuan yang menikah di usia dini belum bisa menanggung beban yang sangat berat dan bahkan anak perempuan bisa mengalami stress karena memang belum waktunya untuk menanggung beban yang sangat berat tersebut. Hal tersebut sangat terasa sesaat setelah anak perempuan berpisah dengan keluarganya dan bertanggungjawab atas keluarganya sendiri. Hal lainnya yang menjadi dampak buruk pernikahan dini adalah rentannya kekerasan dalam rumah tangga (KDRT). Menurut hasil temuan yang dilakukan oleh Plan, sejumlah $44 \%$ anak perempuan yang kawin dini, mengalami kasus KDRT dalam frekuensi yang tinggi. Dan sisanya 56\% yang tidak nikah dini mengalami KDRT dalam frekuensi yang rendah. Selain itu, nikah dini juga memiliki dampak pada kesehatan siem reproduksi anak perempuan. Anak perempuan yang berumur 10-14 tahun berpotensi lima kali lebih berisiko pada masa kehamilan dan melahirkan, dibanding dengan ibu hamil yang usianya 20-25 tahun. Dapat disimpulkan, bahwa pernikahan dini memposisikan anak perempuan sebagai kelompok yang rentan terkait dengan kesehatan reproduksi dan seksualitasnya (Djamilah, 2014).

Agama Islam memandang pernikahan merupakan perjanjian yang sakral, bermakna ibadah kepada Allah, mengikuti Sunnah Rasulullah dan dilaksanakan atas dasar keikhlasan, tanggung jawab, dan mengikuti ketentuan-ketentuan hukum yang harus dilakukan. Dalam Undang-Undang RI Nomor 1 tahun 1974 tentang Perkawinan Bab I pasal 1, perkawinan adalah ikatan lahir batin antara seorang pria dengan seorang wanita sebagai suami-istri dengan tujuan membentuk keluarga yang bahagia dan kekal berdasarkan Ketuhanan Yang Maha Esa.

Dalam ajaran Islam, menikah salah satu ibadah yang dianjurkan. Karena dengan menikah seseorang akan membina rumah tangga dan membentuk keluarga sakinah, mawaddah, dan wa rahman. Menjalin silaturahmi dengan keluarga dan memiliki keturunan. Selain itu juga menghindari zina. 
Dalam Islam, zina adalah haram. Maka diperintahkan untuk menikah bagi yang mampu dan berpuasa bagi yang belum mampu (Kompas.com, 2020).

Tujuan dari pernikahan sendiri tidak hanya untuk memenuhi kebutuhan biologis, akan tetapi yakni menaati perintah Allah dan Rasul-Nya bernilai ibadah yaitu membina keluarga sejahtera yang mendatangkan kemaslahatan bagi para pelaku perkawinan, anak keturunan juga kerabat. Perkawinan sebagai suatu ikatan yang kokoh, dituntut untuk membuat kemaslahatan bagi masyarakat juga bangsa pada umumnya.

Berdasarkan beberapa definisi tersebut diatas, dapatlah penulis simpulkan, bahwasanya beberapa tujuan dari pernikahan adalah untuk membentuk keluarga (rumah tangga) yang bahagia dan kekal berdasarkan ketuhanan yang Maha Esa, menyempurnakan sunnatulah dan memperoleh keturunan.

Desa berinding adalah sebuah Desa pemekaran dari kopang rembige yang letaknya dekat dari pusat informasi dan pendidikan, tapi kesadaran terhadap hukum masih sangat rendah, hal ini dapat di lihat dengan tingginya kasus pernikahan di usia dini. Oleh karena itu, saya tertarik mengadakan penyuluhan mengenai Faktor dan Implikasi penikahan dini di daerah tersebut. Tujuan dari kegiatan penyuluhan ini adalah:

a) Memberikan informasi mengenai dampat dari pernikahan dini

b) Mengetahui penyebab terjadinya pernikahan usia dini di Desa Berinding

c) Mengetahui dampak dari pernikahan di usia dini bagi masyarakat Desa Berinding

d) Mengetahui akibat dari pernikahan usia dini menurut prespektif hukum Islam.

Setelah mengikuti penyuluhan hukum ini diharapkan peserta penyuluhan dapat berperan aktif dalam menyebarluaskan tentang dampak dari pernikahan usia dini.

\section{METODE}

Penyuluhan hukum di Desa Berinding Kabupaten Lombok Tengah ini dilaksanakan dalam bentuk ceramah dan diskusi. penyampaian materi dan penyuluhan dalam tatap muka secara langsung kepada peserta dengan alokasi waktu yang telah ditetapkan tatap muka secara langsung melalui ceramah. Dalam penyuluhan ini disampaikan 2 materi yang berjudul "Faktor-Faktor Penyebab Terjadinya Pernikahan Usia Dini" dan "Dampak Negatif Menikah Di Usia Dini Bagi Kesehatan Reproduksi Perempuan". Setelah materi disampaikan, selanjutnya masuk pada tahap diskusi, yaitu membuka kesempatan tanya jawab atau diskusi mengenai materi yang telah disampaikan. Adapun yang menjadi khalayak sasaran dalam kegiatan ini adalah aparat desa, kepala-kepala dusun, tokoh agama dan tokoh masyarakat dan masyarakat umum yang ada di Desa Berinding Kabupaten Lombok Tengah.

Dalam pelaksanaan kegiatan ini terdapat berbagai faktor pendorong serta faktor penghambat yang menjadi kendala dalam pelaksanaan kegiatan penyuluhan. Faktor-faktor ini kemudian menjadi dasar untuk melakukan evaluasi terhadap hasil pengabdian masyarakat.

Faktor pendorong: Keterbukaan kepala desa beserta stafnya dalam menerima penyuluhan dan penyusunan jadwal pelaksanaan penyuluhan, serta antusiasme yang tinggi dari peserta penyuluhan dalam mengikuti kegiatan penyuluhan mulai dari sesi penyampaian materi sampai sesi dialog.

Faktor penghambat: Molornya waktu kegiatan penyuluhan hukum dilakukan karena para peserta tidak serempak hadir di tempat kegiatan dengan berbagai alasan. 


\section{HASIL DAN PEMBAHASAN}

Kegiatan penyuluhan hukum mengenai "Pernikahan Usia Dini, Faktor Dan Implikasinya Perspektif Hukum Islam di Desa Persiapan Berinding, Kopang, Lombok Tengah" dihadiri oleh aparat desa, kepala-kepala dusun, tokoh agama dan tokoh masyarakat dan masyarakat umum yang ada di desa Berinding. Pada kegiatan penyampaian materi yang berjudul "Faktor-Faktor Penyebab Terjadinya Pernikahan Usia Dini” dan "Dampak Negatif Menikah Di Usia Dini Bagi Kesehatan Reproduksi Perempuan".

\section{Faktor-Faktor Penyebab Terjadinya Pernikahan Usia Dini}

Berdasarkan study lapangan ditemukan sebuah gambaran yang menjelaskan bahwa terdapat sebuah bahwa kemiskinan yang terjadi di dalam sebuah keluarga sangat berdampak besar terhadap masa depan seorang anak, terutama pada anak remaja. Seorang remaja yang seharusnya melanjutkan tugas perkembangan sesuai dengan usianya, kini harus menikah dengan usia yang masih muda dengan hanya memiliki tingkat pendidikan yang rendah. Orangtua yang memiliki tingkat ekonomi yang rendah selalu tergesa-gesa untuk menikahkan anak perempuannya di usia muda. Hal ini dilakukan oleh para orangtua agar bisa mengalihkan beban mereka kepada menantunya. Hal ini kemudian didukung oleh kategori pola asuh orangtua yang demokratik dimana pola asuh ini kurang signifikan dikarenakan orangtua tidak mengekang pada anak-anaknya dan memaksakan kehendaknya pada anak-anaknya, sebaliknya mereka memberikan kepercayaan atau kebebasan terhadapa anak-anaknya untuk bisa menjalani kehidupan dimasa yang akan mendatang. Pola asuh orangtua tersebut seperti kurangnya nasehat yang diberikan kepada anak mengenai bahayanya menikah di usia muda dan kehidupan dalam menjalani rumah tangga dengan usia yang relatif masih sangat muda dan peranan orangtua yang sangat dominan dalam menentukan perkawinan anak perempuan, karena anggapan bahwa anak adalah milik, sehingga anak terutama anak perempuan harus senantiasa berbakti/patuh kepada orangtua. Kurangnya perhatian pemerintah dalam menangani kasus perkawinan dibawah umur, seperti UndangUndang Perkawinan No. 1 tahun 1974 yang memperbolehkan pernikahan anak perempuan pada usia 16 tahun dan laki-laki 19 tahun, yang seharusnya sudah terdapat perubahan karena sudah tidak sesuai dengan keadaan saat ini. Terdapat beberapa faktor yang dianalisis pada poin ini, yaitu :

1. Faktor orangtua dalam pembentukan konsep diri remaja yang menikah dini,

2. Faktor kelompok rujukan dalam konsep diri remaja yang menikah dini, yang dimana setiap kelompok mempunyai norma-norma tertentu.

\section{Dampak Negatif Menikah Di Usia Dini Bagi Kesehatan Reproduksi Perempuan}

Menurut Survey Demografi Kesehatan indonesia tahun 2017, ditemukan adanya penurunan penggunaan kontrasepsi modern pada segmen usia muda (15-29 tahun) secara signifikan sebesar 4 persen. Hal ini juga berpengaruh kepada tingginya kehamilan remaja di Indonesia yang diperkirakan sampai dengan 500 ribu kehamilan remaja perempuan setiap tahunnya. Rendahnya pengetahuan anak muda terhadap kesehatan reproduksi (KESPRO) dan kurangnya akses terhadap informasi yang akurat dan terpercaya tentang kontrasepsi disinyalir menjadi dua penyebab utama hal tersebut.

Kedua fakta itulah yang kini tengah menjadi perhatian utama pemerintah Indonesia. Bukan tanpa sebab, kemajuan teknologi yang begitu pesat membuat para remaja dan generasi millennials lebih mudah dalam mengakses konten-konten berbau pornografi dan terjerumus dalam pergaulan bebas. Hal tersebut secara tidak langsung memicu peningkatan angka kehamilan remaja di Indonesia. 
Menurut dr. UF Bagazi, SpOG dari RS. Brawijaya Antasari, kehamilan pada masa remaja sebaiknya dihindari karena menimbulkan banyak sekali efek negatif. Tidak hanya menyangkut kesehatan tubuh saja, tetapi juga berdampak pada kesehatan psikologinya. "Minarke atau men situ pertama kali dialami oleh anak wanita pada usia 12-13 tahun. Namun sayangnya, tidak banyak yang mengetahui bahwa pada masa inilah perbandingan antara mulut dan bagian atas rahim masih memiliki proporsi yang sama 1:1," tutur UF Bagazi, dalam konferensi Hari Kontrasepsi Sedunia bersama DKT Indonesia, di kawasan Jakarta Selatan, Selasa (25/9/2018).

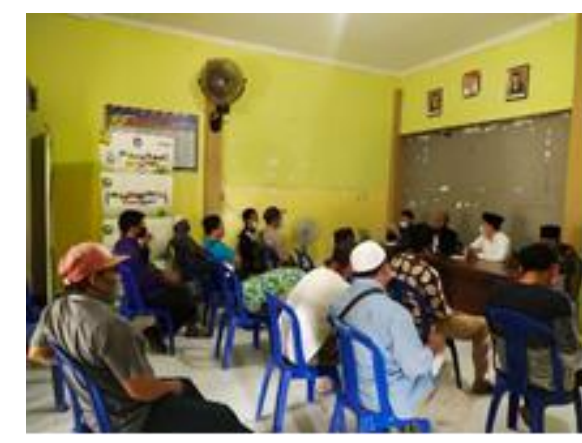

Gambar 1. Penyuluh memberikan materi hukum

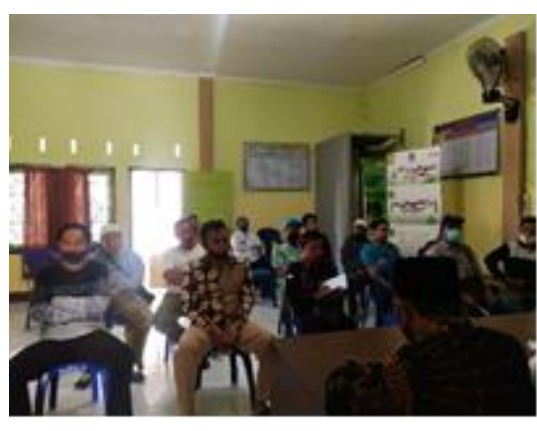

Gambar 2. Peserta mendengarkan materi yang disampaikan

Dampak yang bisa terjadi pada remaja yang hamil di usia terlalu muda: terjadi kematian ibu dan bayi karna perempuan remaja masih terus mengalami pertumbuhandan umumnya belum siap menjalani proses persalinan karena panggul sempit, bisa terjadi kelainan pada bayi, terjadi komplikasi kehamilan, berat badan lahir bayi rendah, penyakit menular seksual, depresi pasca melahirkan. (Indarti, 2020).

\section{KESIMPULAN DAN SARAN}

Berdasarkan kegiatan penyuluhan ini diperoleh kesimpulan bahaw faktor-faktor pendorong terjadinya perkawinan pada usia muda di lokasi penelitian ini antara lain: faktor ekonomi, faktor keluarga, faktor pendidikan, faktor kemauan sendiri, dan faktor adat setempat. Remaja yang memutuskan untuk menikah di usia muda pada umumnya beranggapan bahwa pendidikan bagi mereka adalah formalitas. Berdasarkan hasil evaluasi yang dilakukan oleh penyuluh setelah selesai kegiatan penyuluhan ini secara umum dapat dikatakan bahwa para peserta baru mengetahui materi yang disampaikan. Kurangnya kesadaran masyarakat terhadap perilaku menyimpang yang dilakukan oleh laki-laki dan perempuan (pernikahan dini) terutama di kalangan remaja yang secara medis belum cukup umur, mengakibatkan praktik tersebut masih terjadi. Sehingga sudah menjadi tugas bersama bagi para orang tua dalam mendidik anaknya dengan sebaik-baiknya baik dalam bidang agama dan pendidikan agar anak-anak kita terhindar dari perbuatan tersebut.

\section{DAFTAR PUSTAKA}

Candraningrum, D. 2016. Pernikahan Anak: Status Anak Perempuan? JurnL Perempuan. Vol 1, hal 15.

Djamilah, Kartikawati R., 2014. Dampak Perkawinan Anak di Indonesia. Jurnal Studi Pemuda. Vol 1, hal 1-16. 
Halodoc.com. Dampak Kesehatan Fisik dan Mental Pernikahan Dini bagi Remaja, https://www.halodoc.com/artikel/dampak-kesehatan-fisik-dan-mental-pernikahan-dini-bagiremaja, diakses pada tanggal 26 Juni 2020

Indarti, 2020.Teenage Pregnancy: Obstetric and Perinatal outcome in a Tertiary Centre in indonesia.

Kompas.com. Dasar Hukum Pernikahan dalam https://www.kompas.com/skola/read/2020/06/13/194500669/dasar-hukum-pernikahandalam-islam?page=all, diakses tanggal 13 Juni 2020

Muntamah A.L., Latifani, D., Arifin, R. 2019. Pernikahan dini di indonesia: faktor dan peran pemerintah (perspektif penegakan dan perlindungan hukum bagi anak). Jurnal Widya Yuridika. Vol 1, hal 1-12, http://publishing-widyagama.ac.id/ejournalv2/index.php/yuridika/article/view/823/804. 